\title{
Chemistry of a 1,5-Oligosilanylene Dianion Containing a Disiloxane Unit
}

\author{
Rainer Zitz, Judith Baumgartner,*(-) and Christoph Marschner*(i) \\ Institut für Anorganische Chemie, Technische Universität Graz, Stremayrgasse 9, 8010 Graz, Austria
}

Supporting Information

ABSTRACT: Synthesis of a number of disiloxane containing cycloand bicyclooligosilanes is described starting from the dipotassium 1,5oligosiloxanylene diide derived from 1,3-bis[tris(trimethylsilyl)silyl]tetramethyldisiloxane. In addition, the use of this particular fragment as ligand for zinc and group 4 metallocene complexes was studied. Both types of compounds exhibit marked structural differences compared to related compounds containing $\mathrm{Si}-\mathrm{Si}$-Si units instead of the $\mathrm{Si}-\mathrm{O}-\mathrm{Si}$ fragment.

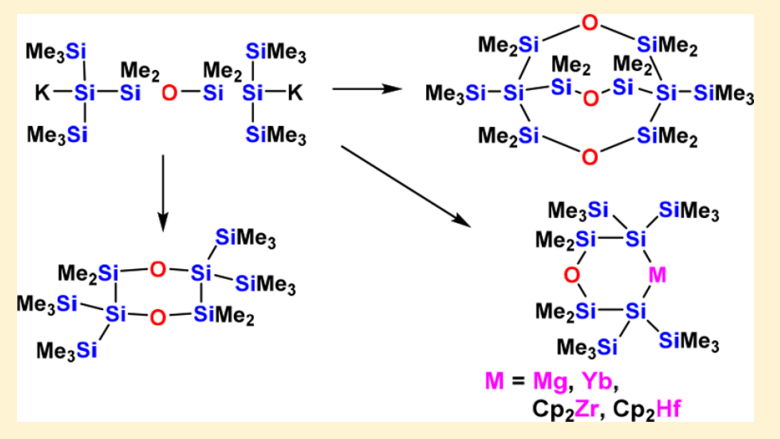

\section{INTRODUCTION}

Over the past years, we have utilized oligosilanylene diides ${ }^{1-4}$ for the synthesis of longer oligosilane chains, ${ }^{5-10}$ cyclosilanes, ${ }^{2,7,11-14}$ heterocyclosilanes, ${ }^{11,12,15,16}$ and as ligands for silyl transition metal complexes ${ }^{1,4,17-22}$ and silylated low valent main group compounds. ${ }^{23-30}$

Usually methylated oligosilanylene units were used as the connecting units between the two silyl anionic atoms of these compounds. Such spacer parts generally do not interact with a newly incorporated heteroatom and are mainly responsible for conformational properties. However, our recent studies concerning the use of silanides as ligands for lanthanide complexes $^{31-34}$ have brought about the necessity of incorporating additional donor sites into the ligand backbone. These additional donor sites for the metal atom should avoid or diminish the coordination of solvent molecules like THF or DME to the metal atoms. Solvent free lanthanide complexes allow the use of vacuum during workup procedures and do not restrict the solvent use in order to ensure a homogeneous product distribution. For this reason, we have prepared several different silylated siloxanes, and in doing so, disiloxane $\mathbf{1}$ (Scheme 1) turned out to be an easily available ligand with great opportunities for further transformations, leading to a variety of interesting new compounds. Furthermore, theoreti$\mathrm{cal}^{35,36}$ and synthetic aspects ${ }^{37-41}$ of siloxanes have gained considerable attraction in recent times. Despite the large structural variety of oligosilanes that have been prepared over the past years, compounds with $\mathrm{Si}-\mathrm{Si}$ bonds and $\mathrm{Si}-\mathrm{O}-\mathrm{Si}$ units are not very abundant. While such compounds are available by controlled hydrolysis of $\alpha, \omega$-dichlorooligosilanes, ${ }^{42}$ examples with even slightly more complex molecular architecture are rather rare. Nevertheless, Krempner et al. have shown that dendritic oligosilanes with discrete disiloxane units are interesting compounds for the modeling of oxygen defects in
Scheme 1. Synthesis of 1,3-

Bis[tris(trimethylsilyl)silyl] tetramethyldisiloxane (1) and Its Conversion to the 1,5-Oligosilanylene Diide 2

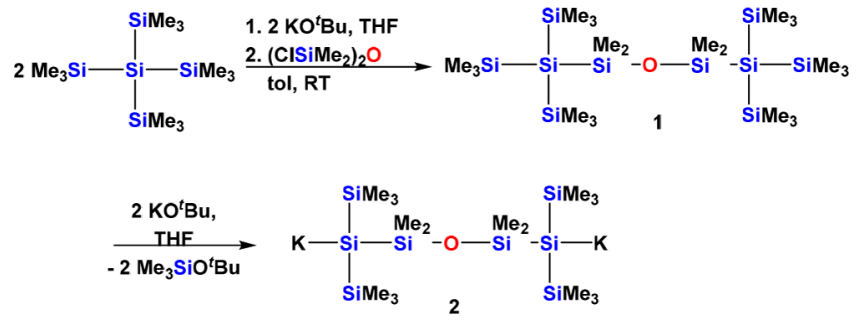

silicon nanomaterials ${ }^{43}$ and von Hänisch and co-workers have recently incorporated oligosiloxane units into crown ethers. ${ }^{44}$

Upon treatment with 2 equiv ${ }^{t} \mathrm{BuOK}$, disiloxane 1 can be converted to the respective oligosilanylene diide $\mathbf{2}$ (Scheme 1). ${ }^{33}$

In the reactions of dianion 2 with $\mathrm{YbI}_{2} \cdot(\mathrm{THF})_{2}$ and $\mathrm{SmI}_{2}$. $(\mathrm{THF})_{2}$, it acted as a tridentate ligand to $\operatorname{Ln}(\mathrm{II})$, leading to complexes 3 (Scheme 2). ${ }^{33}$ The fact that the lanthanide ion coordinates to the very weakly basic siloxane oxygen ${ }^{45}$ is likely caused by the ion's very strong Lewis acidity.

With a convenient access to disiloxane 1 and the respective dianionic derivative 2 , we thought it would be interesting to use these as precursors for the design of oligosilanes with even more siloxane units and also for the formation of additional silyl-metal complexes.

Received: January 11, 2019

Published: February 28, 2019 
Scheme 2. Formation of Ytterbium and Samarium Disilyl Complexes 3 by Reaction of Dianion 2 with the Respective Metal Diiodides

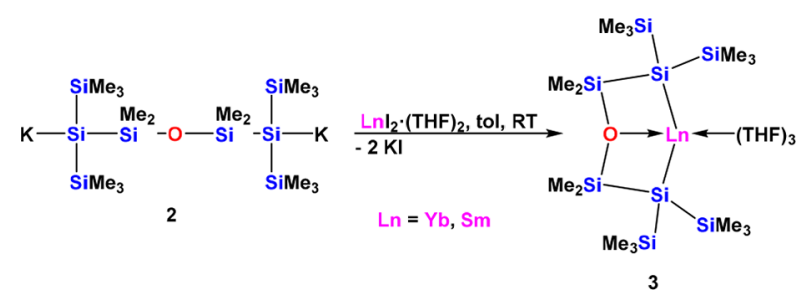

RESULTS AND DISCUSSION

Disiloxane Containing Oligosilanes. With compound 2 readily available, we decided to study its chemistry in more detail. By addition of 1,2-dibromoethane, oxidative coupling of the two silanide moieties ${ }^{46}$ was achieved, yielding oxacyclopentasilane 4 (Scheme 3). In the case of using a slight excess of

Scheme 3. Formation of Oxacyclopentasilane 4 by Oxidative Cyclization of 2. Side Product 5 Can Be Converted to 4 by Reductive Coupling with Potassium Graphite

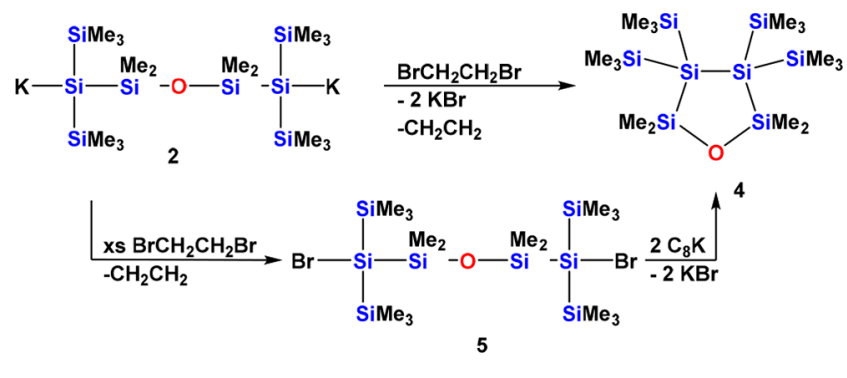

1,2-dibromoethane, in addition to 4 also the 1,5-dibromide 5 was formed as a side product, which was converted to 4 by reaction with added potassium graphite (Scheme 3 ).

The ${ }^{29} \mathrm{Si}$ NMR spectrum of compound 4 (Table 1) features expected values for $\mathrm{SiMe}_{3}(-9.6 \mathrm{ppm})$, and $\mathrm{Si}\left(\mathrm{SiMe}_{3}\right)_{2}$ $(-132.2 \mathrm{ppm})$. For the disiloxane unit, a resonance at 20.9 ppm was observed, which is somewhat downfield shifted compared to acyclic products $\mathbf{1}$ and $\mathbf{5}$ (Table 1 ), as can be expected for the diminished $\mathrm{Si}-\mathrm{O}-\mathrm{Si}$ angle in a cyclic compound.

Reaction of oligosilanylene diide 2 with 1,3-dichlorotetramethyldisiloxane gave the expected 1,5-dioxacyclooctasilane 6 (Scheme 4). Further reaction of 6 with 2 equiv of ${ }^{t} \mathrm{BuOK}$ provided the respective 1,5-dioxacyclooctasilanyl-3,7-diide 7 . Subjecting 7 to 1,2-dibromoethane causes coupling of the two silanide units to form 3,7-dioxabicycle[3.3.0] octasilane 8 (Scheme 4). Alternatively, disilanide 7 can react with another equiv of 1,3-dichlorotetramethyldisiloxane, yielding dodecamethyl-1,5-bis (trimethylsilyl)-3,7,10-trioxa-octasilabicyclo[3.3.3] undecane (9) (Scheme 4). NMR spectroscopic analysis of reactions leading to 8 and 9 revealed that both reactions are not entirely selective. Presumably oligomers or polymers connecting 1,5-dioxacyclooctasilane rings are formed as side products. This can be concluded from the ${ }^{13} \mathrm{C}$ NMR spectra, which feature a fair number of small signals in close proximity to the $\mathrm{SiMe}_{2}$ and $\mathrm{SiMe}_{3}$ signals (see f.i. Figure S15).

Compound 9 still has two trimethylsilyl groups originating from precursor 1, located at the bridgehead positions. Additions of further 2 equiv of ${ }^{t} \mathrm{BuOK}$ cleaved off these
Table 1. Selected NMR Spectroscopic Data of Oligosilanyl Disiloxane Containing Compounds in ppm

\begin{tabular}{lccll} 
& ${ }^{29} \mathrm{Si}\left(\mathrm{SiMe}_{3}\right)$ & ${ }^{29} \mathrm{Si}\left(\mathrm{SiMe}_{2} \mathrm{O}\right)$ & ${ }^{29} \mathrm{Si}\left(\mathrm{Si}_{\mathrm{q}}\right)$ & \multicolumn{1}{c}{${ }^{29} \mathrm{Si}(\mathrm{Si}-\mathrm{E})$} \\
$\mathbf{1}^{a}$ & -10.5 & 13.4 & -132.8 & n.a. \\
$\mathbf{2}^{a}$ & -7.0 & 27.6 & n.a. & $-185.7(\mathrm{SiK})$ \\
$\mathbf{3}$ & -5.0 & 32.4 & n.a. & $-153.8(\mathrm{SiYb})$ \\
$\mathbf{4}$ & -9.6 & 20.9 & -132.2 & n.a. \\
$\mathbf{5}$ & -13.0 & 6.9 & -28.9 & n.a. \\
$\mathbf{6}$ & -11.2 & 11.6 & -132.2 & n.a. \\
7 & -9.9 & 24.7 & n.a. & $-188.0(\mathrm{SiK})$ \\
$\mathbf{8}$ & -10.0 & 22.2 & -132.9 & n.a. \\
$\mathbf{9}$ & -15.3 & 10.9 & -136.2 & n.a. \\
$\mathbf{1 0}$ & n.a. & 15.5 & n.a. & $-186.7(\mathrm{SiK})$ \\
$\mathbf{1 1}$ & -12.6 & 11.9 & n.a. & $-116.5(\mathrm{SiH})$ \\
$\mathbf{1 2}$ & -14.9 & 5.9 & n.a. & $-19.7(\mathrm{SiCl})$ \\
$\mathbf{1 3}$ & -12.3 & 8.4 & n.a. & $-18.5(\mathrm{SiN})$ \\
$\mathbf{1 4}$ & -16.9 & 1.6 & n.a. & $-7.0(\mathrm{SiO})$ \\
$\mathbf{1 5}$ & -8.8 & 20.6 & n.a. & $-155.7(\mathrm{SiYb})$ \\
$\mathbf{1 6}$ & -7.3 & 15.2 & n.a. & $-166.9(\mathrm{SiMg})$ \\
$\mathbf{1 7}$ & -5.8 & 16.3 & n.a. & $-142.0(\mathrm{SiZn})$ \\
$\mathbf{1 8}$ & -5.6 & 18.2 & n.a. & $-71.5(\mathrm{SiZr})$ \\
$\mathbf{1 9}$ & -4.9 & 13.3 & n.a. & $-45.7(\mathrm{SiHf})$ \\
& & & &
\end{tabular}

${ }^{a}$ Data taken from ref 33 .

groups and converted 9 to [3.3.3] bicyclo-1,5-potassium disilanide 10 (Scheme 4).

The eight-membered ring of $\mathbf{6}$ allows for a widened $\mathrm{Si}-\mathrm{O}-$ $\mathrm{Si}$ angle, and accordingly, the ${ }^{29} \mathrm{Si}$ NMR chemical shift of the siloxane silicon atoms $(11.6 \mathrm{ppm})$ is close to that of the acyclic compound 1 (13.4 ppm) (Table1). Correspondingly, the ${ }^{29} \mathrm{Si}$ NMR spectrum of the respective 1,4-dianionic compound 7 resembles that of compound 2 (Table 1 ).

The 3,7-dioxabicyclo[3.3.0] octasilane $\mathbf{8}$ is structurally very similar to 4 . This is clearly reflected by its ${ }^{29} \mathrm{Si} \mathrm{NMR}$ spectrum which resembles that of 4 . In a similar sense, compound 9 is structurally related to 6 . The ${ }^{29} \mathrm{Si}$ NMR resonances of the trimethylsilyl groups of 1,33 , and 9 experience upfield shift in this order. Compound 9 is a rare example of a tricyclic oligosiloxane. A somewhat related bicyclo[3.3.3] pentasiloxane was recently obtained by Iwamoto and co-workers using $m$ CPBA oxidation of a 1,3-bis(trimethylsilyl)bicyclo[1.1.1]pentasilane. ${ }^{37}$ Compound 10 features a very simple ${ }^{29} \mathrm{Si}$ NMR spectrum with only two lines; the typical upfield resonances for the anionic silicon atoms $(-186.7 \mathrm{ppm})$ are accompanied by a peak at $15.5 \mathrm{ppm}$ for the $\mathrm{SiO}$ units. The compound might be regarded as a building block for the synthesis of low dimensional materials such as one-dimensional nanorods consisting of bridgehead connected bicyclo[3.3.3] trisiloxane units. $^{37}$

Facile protonation of oligosilanylene diide $\mathbf{2}$ yielded the respective 1,5-dihydrosilane 11 . Reaction with tetrachloromethane converted 11 to the 1,5-dichlorooligosilane 12 (Scheme 5). ${ }^{47}$ Further reaction of $\mathbf{1 2}$ with excess diethylamine gave 1,5-bis(diethylamino)oligosilanyldisiloxane $13,{ }^{47}$ which upon reaction with aqueous methanol led to the rather unexpected formation of 1,4-dioxacyclohexasilane 14. We assume that $\mathbf{1 4}$ forms via an intermediate oligosilane diol, which in the presence of $\mathrm{Et}_{2} \mathrm{NH}$ is partly deprotonated. Attack of the respective siloxide at a $\mathrm{SiMe}_{2}$ unit leads to a rearranged oligosilane diol, which upon water elimination can cyclize to 14 (Scheme S1). 
Scheme 4. Preparation of 1,5-Dioxacyclooctasilane 6, Its Conversion to the Respective 3,7-Disilanide 7, Which Can Further Be Used for the Synthesis of 3,7-Dioxabicyclo[3.3.0] octasilane 8 and 1,5-Bis(trimethylsilyl)-3,7,10-trioxa-

octasilabicyclo[3.3.3] undecane 9
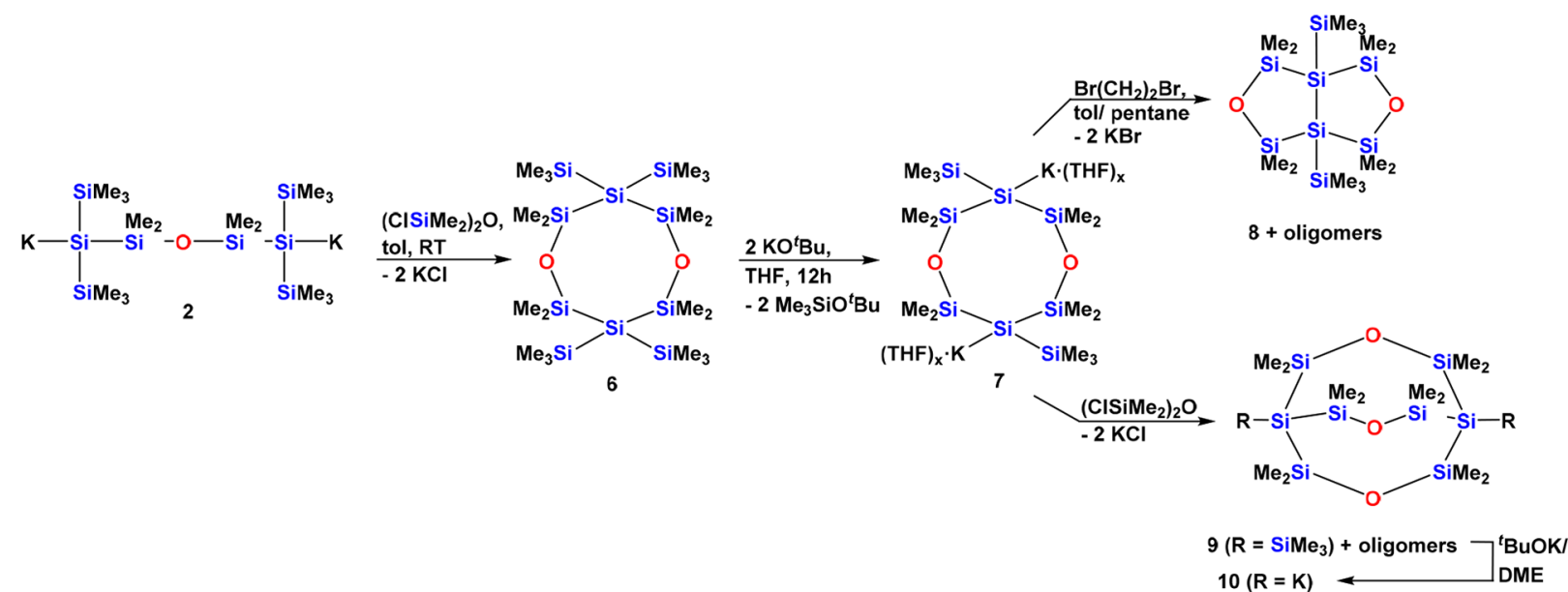

Scheme 5. Formation of 1,5-Dihydrosilane 11, Followed by Chlorination (12), and Amination (13). Hydrolysis of 13 Yields 1,4-Dioxacyclohexasilane 14

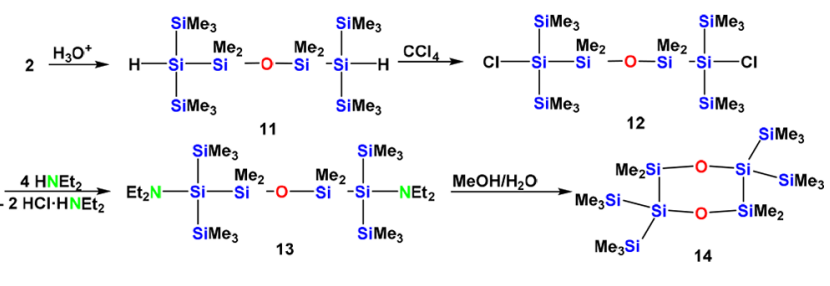

Quite typically, dihydrooligosilane 11 was obtained as an oil. Its ${ }^{29} \mathrm{Si}$ NMR spectroscopic properties are very much as expected. The $\mathrm{Si}-\mathrm{H}$ resonance at $-116.5 \mathrm{ppm}$ is close to the respective signal of $\left(\mathrm{Me}_{3} \mathrm{Si}\right)_{3} \mathrm{SiH}(-115.4)$, and also the trimethylsilyl signal at $-12.6 \mathrm{ppm}$ is in line with the -10.9 ppm observed for $\left(\mathrm{Me}_{3} \mathrm{Si}\right)_{3} \mathrm{SiH}^{46}$

In a similar way, the ${ }^{29} \mathrm{Si}$ NMR signature of oligosilanyldichloride $12\left(5.9(\mathrm{SiO}),-14.9\left(\mathrm{SiMe}_{3}\right),-19.7(\mathrm{SiCl}) \mathrm{ppm}\right)$ reflects the similarity of 12 to $\left(\mathrm{Me}_{3} \mathrm{Si}\right)_{3} \mathrm{SiCl}\left(-11.6\left(\mathrm{SiMe}_{3}\right)\right.$, $-13.3(\mathrm{SiCl}) \mathrm{ppm}) .{ }^{48}$ Compound 13 features the trimethylsilyl and $\mathrm{NS} i$ resonances at $-12.3 \mathrm{ppm}$ and $-18.5 \mathrm{ppm}$, respectively. Compared to the previously prepared $\mathrm{Et}_{2} \mathrm{NSi}(\mathrm{Si}$ $\left.\mathrm{Me}_{3}\right)_{2}\left(\mathrm{SiMe}_{2}\right)_{2} \mathrm{Si}\left(\mathrm{SiMe}_{3}\right)_{2} \mathrm{NEt}_{2}\left(\delta=-16.0\left(\mathrm{SiMe}_{3}\right),-23.3\right.$ $(\mathrm{SiN})$, and $\left.-38.0\left(\mathrm{SiMe}_{2}\right) \mathrm{ppm}\right),{ }^{47}$ these values are somewhat deshielded, which can be attributed to the presence of the polar Si-O-Si unit.

Metal Complexes with Disiloxane Containing Oligosilanyl Ligands. Silylated lanthanides are an interesting field of research pioneered by Schumann and co-workers. ${ }^{49,50}$ Oligosilylated examples are still investigated by us $^{31-34}$ and others. ${ }^{51-54}$ As mentioned, we initially devised the synthesis of oligosilanylene diide 2 to employ it as a ligand for $\operatorname{Ln}$ (II)-silyl complexes. ${ }^{33}$ As compound 7 can be regarded as a derivative of 2 , containing an additional disiloxane unit, we reacted it with $\mathrm{YbI}_{2}$ (Scheme 6). ${ }^{1} \mathrm{H}$ NMR studies showed that the obtained product $\mathbf{1 5}$ was indeed coordinating to both oxygen atoms as only two THF or one DME molecules were shown to occupy the remaining two of the six coordination sites of $\mathrm{Yb}$.

The clean reaction of $\mathbf{2}$ with $\mathrm{YbI}_{2}$ encouraged us to study its coordination chemistry also with other divalent metal halides (Scheme 7). Not unexpectedly, 2 can be cleanly transmetalated
Scheme 6. Reaction of Dianion 7 with $\mathrm{YbI}_{2}$
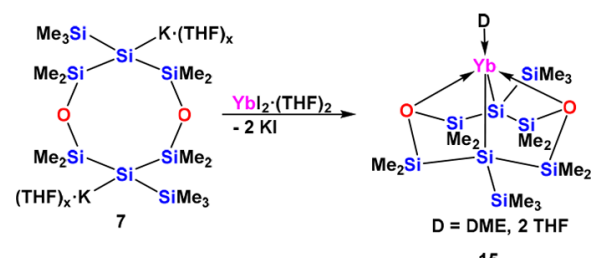

15

Scheme 7. Reaction of Dianion 2 with Other Divalent Metal Complexes

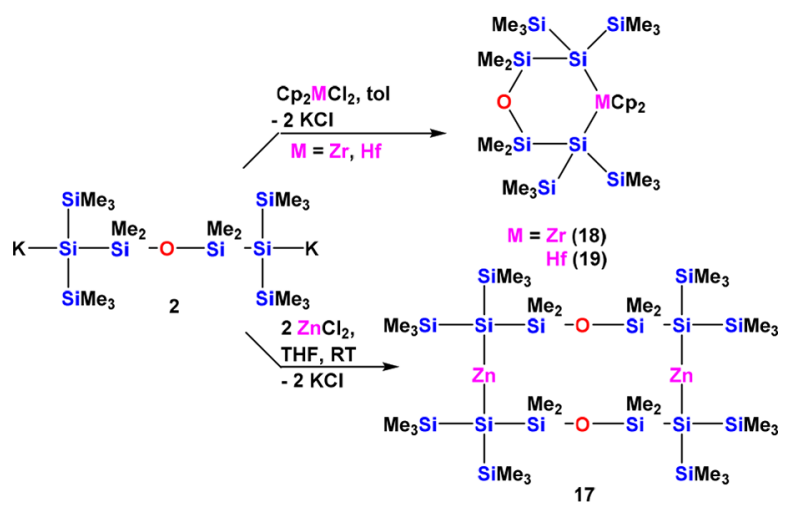

to the respective magnesium compound 16 by reaction with $\mathrm{MgBr}_{2} \cdot \mathrm{Et}_{2} \mathrm{O}$. ${ }^{4,55} 16$ exhibits the typical ${ }^{29} \mathrm{Si}$ NMR spectroscopic signature known for oligosilanyl magnesium compounds. The signal at $-166.9 \mathrm{ppm}$ (Table 1) reflects the diminished anionic character compared to 2 . While the influence of the negative charge on the directly metalated silicon atom is most pronounced, a downfield shift for attached trimethylsilyl groups compared to the neutral precursor molecules is usually observed.

Conversion of oligosilanides with zinc halides to silyl zinc compounds is a well established process. ${ }^{19,34,56-60}$ Reaction of 2 with $\mathrm{ZnCl}_{2}$ was thus attempted (Scheme 7). We expected a six-membered ring to be formed in the reaction; ${ }^{19}$ however, the obtained product $\mathbf{1 7}$ is a 12 -membered ring with close to linear $\mathrm{Si}-\mathrm{Zn}-\mathrm{Si}$ coordination geometry. Earlier studies have already shown a pronounced tendency of the $\mathrm{Si}-\mathrm{Zn}-\mathrm{Si}$ unit to 
acquire linear arrangements. ${ }^{19,56}$ Cases with significant bending of the $\mathrm{Si}-\mathrm{Zn}-\mathrm{Si}$ unit are almost always accompanied by coordination of one or more Lewis bases to the involved $\mathrm{Zn}$ atom. The main reason compound $\mathbf{1 7}$ forms is likely that not only the $\mathrm{Si}-\mathrm{Zn}-\mathrm{Si}$ unit preference for linear arrangement but also the Si-O-Si part's tendency for engaging in larger angles. ${ }^{29} \mathrm{Si} \mathrm{NMR}$ resonances at $-5.8\left(\mathrm{SiMe}_{3}\right)$ and $-142.0(\mathrm{SiZn})$ ppm are close to the respective -7.2 and $-123.9 \mathrm{ppm}$ observed for $\left(\mathrm{Me}_{3} \mathrm{Si}\right)_{3} \mathrm{SiZnSi}\left(\mathrm{SiMe}_{3}\right)_{3} .{ }^{56}$

In contrast to the reaction of 2 with $\mathrm{ZnCl}_{2}$, analogous reactions with zirconocene and hafnocene dichlorides gave compounds 18 and 19 with six-membered rings (Scheme 7). At first glance, this is not unexpected. However, our previous attempts to react $\mathrm{Cp}_{2} \mathrm{MCl}_{2}(\mathrm{M}=\mathrm{Zr}$, Hf) with an oligosilanyl 1,5-diide caused eventual formation of $\mathrm{M}$ (III) complexes. ${ }^{17}$ If we would envision a similar course as for the previous reaction, we would have expected that compound 4 would form in the reaction by reductive elimination from 18 and 19. Although it is not quite clear why compounds $\mathbf{1 8}$ and $\mathbf{1 9}$ are stable toward the elimination process, it seems likely that the ring strain of compound 4 is higher than that of 1,1,2,2-tetrakis(trimethylsilyl)hexamethylcyclopentasilane. The reason for this increased strain seems to be the enhanced tendency of the Si-O-Si unit to acquire angles larger than tetrahedral.

${ }^{29} \mathrm{Si}$ NMR chemical shifts of silylated zirconocenes and hafnocenes typically are much deshielded compared to the respective silanides. For structurally related 1-zircona- and 1hafna-2,2,5,5-tetrakis (trimethylsilyl)tetramethylcyclopentasilanes, ${ }^{1}$ values of -65.2 and $-52.2 \mathrm{ppm}$, respectively, were observed. The resonances for $18(-71.5 \mathrm{ppm})$ and $19(-45.7$ $\mathrm{ppm})$ are similar, but the difference between the two metals is more pronounced.

Crystal Structure Analysis. The molecular structure of $\mathbf{4}$ was determined using single crystal XRD analysis (Figure 1).

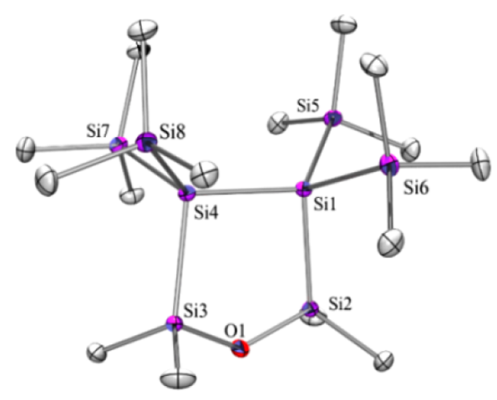

Figure 1. Molecular structure of 4 (thermal ellipsoid plot drawn at the $30 \%$ probability level). All hydrogen atoms are omitted for clarity (bond lengths in $\AA$, angles in deg). O(1)-Si(2) 1.6472(11), O(1)$\mathrm{Si}(3)$ 1.6503(11), $\mathrm{Si}(1)-\mathrm{Si}(6)$ 2.3576(6), $\mathrm{Si}(1)-\mathrm{Si}(5)$ 2.3616(6), $\mathrm{Si}(1)-\mathrm{Si}(2)$ 2.3688(6), $\mathrm{Si}(1)-\mathrm{Si}(4)$ 2.3887(6), $\mathrm{Si}(3)-\mathrm{Si}(4)$ $2.3670(6), \quad \mathrm{Si}(2)-\mathrm{O}(1)-\mathrm{Si}(3) \quad 132.37(7), \quad \mathrm{Si}(2)-\mathrm{Si}(1)-\mathrm{Si}(4)$ $97.10(2), \quad \mathrm{O}(1)-\mathrm{Si}(2)-\mathrm{Si}(1) \quad 105.58(4), \quad \mathrm{Si}(3)-\mathrm{Si}(4)-\mathrm{Si}(1)$ 97.18(2).

The five-membered ring is almost planar (sum of angles is $537^{\circ}$ ) which is caused by a large $\mathrm{Si}-\mathrm{O}-\mathrm{Si}$ angle of $132.4^{\circ}$ (Table 2). As a consequence of the planar arrangement, the $\mathrm{Me}_{3} \mathrm{Si}-\mathrm{Si}-\mathrm{Si}-\mathrm{SiMe}_{3}$ torsional angles are small $\left(16.2^{\circ}\right.$ and $\left.17.0^{\circ}\right)$, causing some steric interaction between the vicinal trimethylsilyl groups. The $\mathrm{Si}(1)-\mathrm{Si}(4)$ distance is therefore slightly elongated (2.3887(6) Å).

Although compound 6 contains an eight-membered ring, in the solid state, a fairly wide $\mathrm{Si}-\mathrm{O}-\mathrm{Si}$ angle of $153.7^{\circ}$ causes
Table 2. Selected Structural Data Derived by Single Crystal XRD Analysis of Compounds 1, 4, 6, 14, 17, 18, and 19

\begin{tabular}{|c|c|c|c|c|}
\hline & $d_{\mathrm{Si} \cdots \mathrm{SiMe} 3}[\AA]$ & $d_{\mathrm{Si} \cdots \mathrm{O}}[\AA]$ & $d_{\mathrm{Si} \cdot \mathrm{E}}[\AA]$ & $\angle_{\mathrm{Si}-\mathrm{O}-\mathrm{SiO}}[\mathrm{deg}]$ \\
\hline $1^{a}$ & $2.358(2)$ & $1.628(6)$ & n.a. & $149.5(5)$ \\
\hline 4 & $\begin{array}{r}2.3533(7)- \\
2.3616(6)\end{array}$ & $\begin{array}{r}1.647(1)- \\
1.650(1)\end{array}$ & n.a. & $132.37(7)$ \\
\hline 6 & $\begin{array}{r}2.3466(8)- \\
2.3466(9)\end{array}$ & $\begin{array}{r}1.630(1)- \\
1.634(1)\end{array}$ & n.a. & $153.68(9)$ \\
\hline 14 & $2.350(1)$ & $\begin{array}{r}1.640(2)- \\
1.663(2)\end{array}$ & n.a. & $143.8(1)$ \\
\hline 17 & $\begin{array}{r}2.343(4)- \\
2.358(3)\end{array}$ & $\begin{array}{r}1.627(6)- \\
1.644(6)\end{array}$ & $\begin{array}{r}2.358(2)- \\
2.380(2)\end{array}$ & $\begin{array}{r}155.2(4) / \\
156.9(4)\end{array}$ \\
\hline 18 & $\begin{array}{r}2.367(1)- \\
2.383(1)\end{array}$ & $\begin{array}{r}1.652(2)- \\
1.653(2)\end{array}$ & $\begin{array}{r}2.820(1)- \\
2.824(1)\end{array}$ & $139.3(2)$ \\
\hline 19 & $\begin{array}{r}2.373(1)- \\
2.385(1)\end{array}$ & $\begin{array}{r}1.651(2)- \\
1.653(2)\end{array}$ & $\begin{array}{r}2.7942(8)- \\
2.7990(8)\end{array}$ & $138.6(1)$ \\
\hline
\end{tabular}

the molecular structure (Figure 2) to engage in a conformation that is similar to a six-membered ring chair conformer.

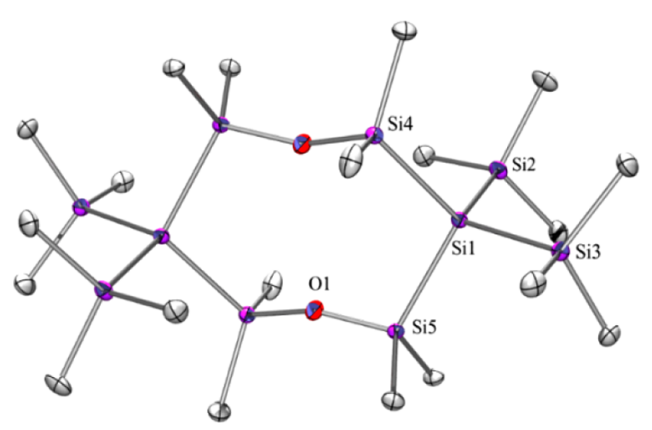

Figure 2. Molecular structure of 6 (thermal ellipsoid plot drawn at the $30 \%$ probability level). All hydrogen atoms are omitted for clarity (bond lengths in $\AA$, angles in deg). $\mathrm{Si}(1)-\mathrm{Si}(4) 2.3428(7), \mathrm{Si}(1)-$ $\mathrm{Si}(2)$ 2.3465(7), $\mathrm{Si}(1)-\mathrm{Si}(3)$ 2.3491(7), $\mathrm{Si}(1)-\mathrm{Si}(5)$ 2.3560(7), $\mathrm{Si}(2)-\mathrm{C}(1)$ 1.8739(19), O(1)-Si(4A) 1.6300(12), Si(4)-Si(1)$\mathrm{Si}(2)$ 109.66(3), Si(4)-Si(1)-Si(3) 113.23(3), Si(2)-Si(1)-Si(3) $110.58(3), \quad \mathrm{Si}(4)-\mathrm{Si}(1)-\mathrm{Si}(5) \quad 105.39(2), \quad \mathrm{Si}(2)-\mathrm{Si}(1)-\mathrm{Si}(5)$ 109.54(2), $\mathrm{Si}(3)-\mathrm{Si}(1)-\mathrm{Si}(5) \quad 108.27(3), \quad \mathrm{Si}(4 \mathrm{~A})-\mathrm{O}(1)-\mathrm{Si}(5)$ $153.68(8)$.

Compounds similar to $\mathbf{1 4}$ are not abundant. The structurally related 1,4-dioxaoctamethylcyclohexasilane was prepared by hydrolylsis of 1,2-dichlorotetramethyldisilane ${ }^{61}$ a long time ago, and its structure was determined by XRD methods more recently. ${ }^{62}$ The structure is quite similar to that of $\mathbf{1 4}$ (Figure 3 ). For both compounds, rather flat rings were observed and $\mathrm{Si}-\mathrm{O}$ bond distances and $\mathrm{Si}-\mathrm{O}-\mathrm{Si}$ angles of both compounds are quite similar.

The molecular structure of $\mathbf{1 7}$ (Figure 4) features a 12membered ring, which, due to almost linear Si-Zn-Si and Si-OSi units, can be regarded as something like an eight-membered ring with very long $\mathrm{Si}-\mathrm{Zn}-\mathrm{Si}$ and long $\mathrm{Si}-\mathrm{O}-\mathrm{Si}$ edges. Its conformation resembles a twisted boat. $\mathrm{Si}-\mathrm{Zn}$ distances between $2.352(2)$ and $2.380(2) \AA$ are clearly longer than found for $\left(\mathrm{Me}_{3} \mathrm{Si}\right)_{3} \mathrm{SiZnSi}\left(\mathrm{SiMe}_{3}\right)_{3}$ which might be caused by the eclipsed arrangement of the $\mathrm{Si}\left(\mathrm{SiMe}_{3}\right)_{2}$ units attached to zinc.

Single crystal structure analysis was performed also on complexes 18 (Figure 5) and 19 (Figure 6). As expected, molecular structures are similar to those of the related zirconaand hafnacyclopentasilanes. ${ }^{1}$ Due to the larger ring size, the $\mathrm{Si}-\mathrm{M}-\mathrm{Si}$ angles of $103.17(3)^{\circ}$ and $101.89(2)^{\circ}$ for $\mathbf{1 8}$ and 19, 


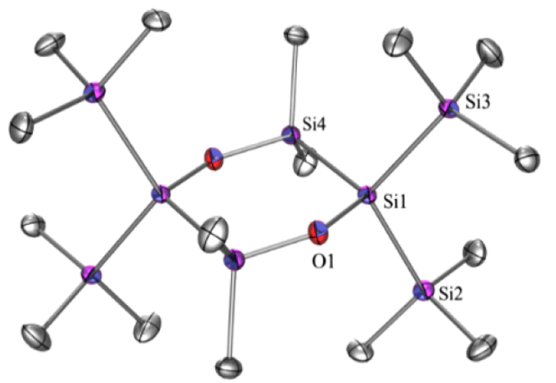

Figure 3. Molecular structure of $\mathbf{1 4}$ (thermal ellipsoid plot drawn at the $30 \%$ probability level). All hydrogen atoms are omitted for clarity (bond lengths in $\AA$, angles in deg). $\mathrm{Si}(1)-\mathrm{O}(1)$ 1.664(2), $\mathrm{Si}(1)-$ $\mathrm{Si}(3)$ 2.3500(11), $\mathrm{Si}(1)-\mathrm{Si}(2)$ 2.3504(11), $\mathrm{Si}(1)-\mathrm{Si}(4) 2.3948(13)$, $\mathrm{Si}(2)-\mathrm{C}(1)$ 1.869(3), $\mathrm{Si}(4)-\mathrm{O}(1 \mathrm{~A}) \quad 1.640(2), \mathrm{Si}(3)-\mathrm{Si}(1)-\mathrm{Si}(2)$ 112.12(4), $\mathrm{Si}(3)-\mathrm{Si}(1)-\mathrm{Si}(4)$ 111.67(4), $\mathrm{Si}(2)-\mathrm{Si}(1)-\mathrm{Si}(4)$ $111.76(4), \mathrm{Si}(4 \mathrm{~A})-\mathrm{O}(1)-\mathrm{Si}(1) 143.77(14)$.

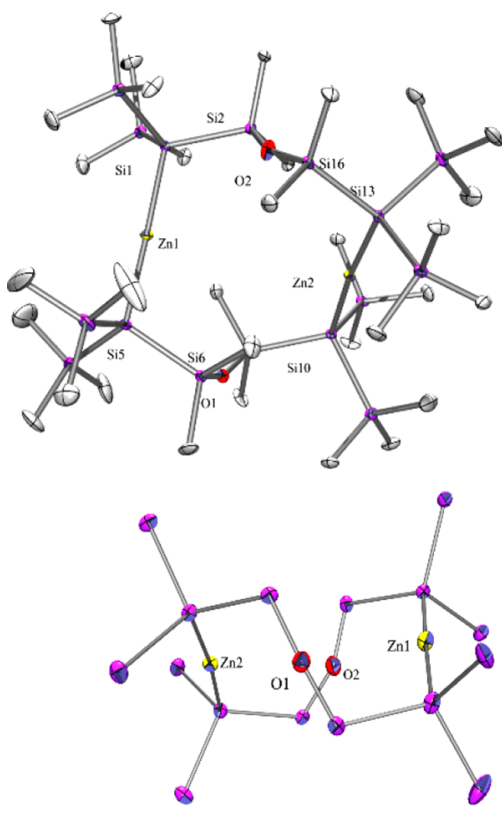

Figure 4. Top: molecular structure of 17 (thermal ellipsoid plot drawn at the $30 \%$ probability level). All hydrogen atoms are omitted for clarity. Bottom: ring conformation without methyl groups (bond lengths in $\AA$, angles in deg). $\mathrm{Zn}(1)-\mathrm{Si}(1)$ 2.358(2), $\mathrm{Zn}(1)-\mathrm{Si}(5)$ 2.373(2), $\mathrm{Zn}(2)-\mathrm{Si}(13)$ 2.376(2), $\mathrm{Zn}(2)-\mathrm{Si}(10)$ 2.380(2), $\mathrm{Si}(1)-$ $\mathrm{Si}(2)$ 2.345(3), $\mathrm{Si}(1)-\mathrm{Si}(3)$ 2.346(3), $\mathrm{Si}(2)-\mathrm{O}(2)$ 1.630(6), $\mathrm{Si}(2)-$ $\mathrm{C}(2) 1.861(8), \mathrm{Si}(6)-\mathrm{O}(1) 1.644(5), \mathrm{Si}(9)-\mathrm{O}(1)$ 1.641(5), $\mathrm{Si}(16)-\mathrm{O}(2)$ 1.626(6), $\mathrm{Si}(1)-\mathrm{Zn}(1)-\mathrm{Si}(5)$ 175.90(8), $\mathrm{Si}(13)-$ $\mathrm{Zn}(2)-\mathrm{Si}(10) \quad 174.33(8), \mathrm{Si}(2)-\mathrm{Si}(1)-\mathrm{Si}(3)$ 106.87(10), Si(2)$\mathrm{Si}(1)-\mathrm{Si}(4)$ 113.65(10), $\mathrm{Si}(3)-\mathrm{Si}(1)-\mathrm{Si}(4)$ 110.70(11), $\mathrm{Si}(9)-$ $\mathrm{O}(1)-\mathrm{Si}(6)$ 155.2(4), $\mathrm{Si}(16)-\mathrm{O}(2)-\mathrm{Si}(2)$ 156.9(4).

respectively, are widened compared to the $97.70(6)^{\circ}$ and $96.42(4)^{\circ}$ of the related metallacyclopentasilanes. $\mathrm{Si}-\mathrm{Zr}$ bond distances of 2.8197(9) and 2.8237(10) $\AA$ are slightly shorter than those of the zirconacyclopentasilane $(2.826(2) / 2.850(2)$ $\AA),{ }^{1}$ and the same is true for the $\mathrm{Si}-\mathrm{Hf}$ bond distances of 2.7943(8) and 2.7990(8) A (hafnacyclopentasilane: 2.791(1)/ 2.826(2) $\AA$ ). Comparison of the ring conformations of $\mathbf{1 8}$ and 19 to those of the related zircona- and hafnacyclopentasilanes ${ }^{1}$ reveals that, despite of the fact that $\mathrm{Si} 2$ and $\mathrm{Si} 3$ are naturally further apart, the conformation is nearly identical.

The $\mathrm{Si}-\mathrm{O}-\mathrm{Si}$ angle of hexamethyldisiloxane has a calculated value of $156.7^{\circ}$ with a very small bending potential. ${ }^{35,36}$ The

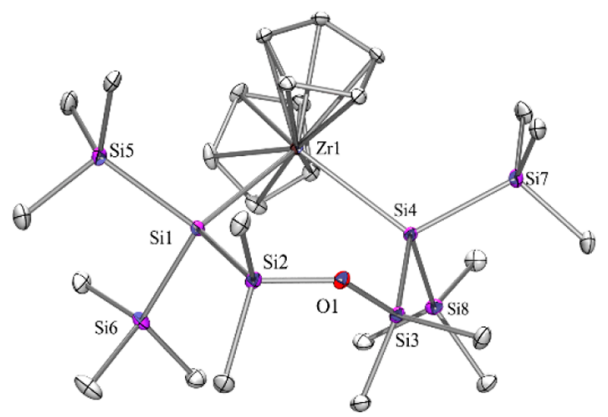

Figure 5. Molecular structure of $\mathbf{1 8}$ (thermal ellipsoid plot drawn at the $30 \%$ probability level). All hydrogen atoms are omitted for clarity (bond lengths in $\AA$, angles in deg). $\operatorname{Zr}(1)-\operatorname{Si}(1) 2.8197(9), \operatorname{Zr}(1)-$ $\mathrm{Si}(4)$ 2.8237(10), $\mathrm{Si}(1)-\mathrm{Si}(2)$ 2.3736(12), $\mathrm{Si}(1)-\mathrm{Si}(5)$ 2.3817(13), $\mathrm{Si}(2)-\mathrm{O}(1)$ 1.651(2), $\mathrm{Si}(2)-\mathrm{C}(11) 1.869(3), \mathrm{Si}(3)-\mathrm{O}(1) 1.653(2)$, $\mathrm{Si}(3)-\mathrm{Si}(4)$ 2.3723(12), $\mathrm{Si}(1)-\mathrm{Zr}(1)-\mathrm{Si}(4)$ 103.17(3), $\mathrm{Si}(2)-$ $\mathrm{Si}(1)-\mathrm{Zr}(1) \quad 105.49(4), \quad \mathrm{Si}(3)-\mathrm{Si}(4)-\mathrm{Zr}(1)$ 104.14(4), $\mathrm{Si}(2)-$ $\mathrm{O}(1)-\mathrm{Si}(3)$ 139.26(14).

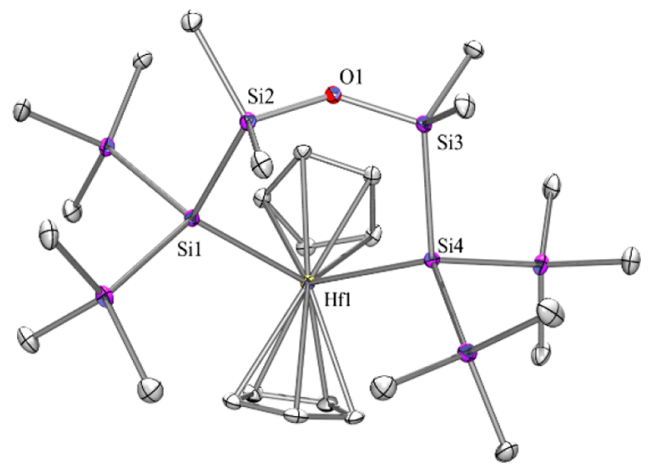

Figure 6. Molecular structure of $\mathbf{1 9}$ (thermal ellipsoid plot drawn at the $30 \%$ probability level). All hydrogen atoms are omitted for clarity (bond lengths in $\AA$, angles in deg). $\mathrm{Hf}(1)-\mathrm{Si}(4) 2.7943(8), \mathrm{Hf}(1)-$ $\mathrm{Si}(1) 2.7990(8), \mathrm{O}(1)-\mathrm{Si}(2)$ 1.6510(18), O(1)-Si(3) 1.6534(18), $\mathrm{Si}(1)-\mathrm{Si}(2)$ 2.3713(10), $\mathrm{Si}(1)-\mathrm{Si}(5)$ 2.3726(11), $\mathrm{Si}(2)-\mathrm{C}(12)$ $1.869(3), \quad \mathrm{Si}(4)-\mathrm{Hf}(1)-\mathrm{Si}(1) \quad 101.89(2), \quad \mathrm{Si}(2)-\mathrm{O}(1)-\mathrm{Si}(3)$ 138.59(12), $\mathrm{Si}(2)-\mathrm{Si}(1)-\mathrm{Hf}(1) \quad 105.49(3), \quad \mathrm{Si}(3)-\mathrm{Si}(4)-\mathrm{Hf}(1)$ $106.57(3)$.

angles in the starting material $1\left(149.5^{\circ}\right)$, in the big rings of 6 $\left(153.7^{\circ}\right)$, and of $17\left(155.2^{\circ}\right)$ are close to this number. For the six-membered rings of 14,18 , and 19 , the angles are diminished to $138.6-143.8^{\circ}$ and once further to a value of $132.4^{\circ}$ for the five-membered ring in 4. As the hyperconjugative effect depends on angular bending, a diminished hyperconjugation in the six- and five-membered rings can be assumed. 35,36

\section{CONCLUSION}

The current work continues our studies of the transformation of siloxane 1 to higher oligosiloxanes and illustrates the use of these compounds as ligands for metal complexes. Utilizing 1, we could demonstrate that cyclic and bicyclic oligosilanes with one or more siloxane units can be prepared. Most of these compounds still contain peripheral trimethylsilyl units and thus can be converted to synthetic building blocks by simple reaction with potassium tert-butoxide.

Reactions of the siloxane containing dipotassium oligosilanylene diide $\mathbf{2}$ with magnesium and zinc halides proceeded smoothly, but for both metals, no interaction with the siloxane oxygen was detected. Somewhat unexpectedly, reactions of $\mathbf{2}$ 
with zirconocene and hafnocene dichlorides occurred to the respective 1-metalla-4-oxacyclohexasilanes. We initially assumed that the latter compounds would undergo reductive elimination to form an oxacyclopentasilane. A likely reason for the stability of the 1-metalla-4-oxacyclohexasilanes is ring strain in the potential reaction product caused by a strong tendency of Si-O-Si units to acquire larger than tetrahedral angles. The synthesized metallaoxacyclosilanes as well as the oxacyclo- and bicyclosilanes exhibit structural features that are different from isostructural homocyclo- and bicyclosilanes, which is mostly caused by $\mathrm{Si}-\mathrm{O}-\mathrm{Si}$ angles significantly larger than the corresponding $\mathrm{Si}-\mathrm{SiMe}_{2}-\mathrm{Si}$ angles.

\section{EXPERIMENTAL SECTION}

General Remarks. All reactions involving air-sensitive compounds were carried out under an atmosphere of dry nitrogen using either Schlenk techniques or a glovebox. Solvents were dried using a column based solvent purification system. ${ }^{63} 1,3-\mathrm{Bis}[$ tris(trimethylsilyl)silyl]1,1,3,3-tetramethyldisiloxane (1) and 1,3-bis[potassiobis(trimethylsilyl)silyl]-1,1,3,3-tetramethyldisiloxane (2) were prepared according to previously published procedures. ${ }^{33}$ All other chemicals were obtained from different suppliers and used without further purification.

${ }^{1} \mathrm{H}(300 \mathrm{MHz}),{ }^{13} \mathrm{C}(75.4 \mathrm{MHz})$, and ${ }^{29} \mathrm{Si}(59.3 \mathrm{MHz}) \mathrm{NMR}$ spectra were recorded on a Varian INOVA 300 spectrometer and are referenced to tetramethylsilane (TMS) for ${ }^{1} \mathrm{H},{ }^{13} \mathrm{C}$, and ${ }^{29} \mathrm{Si}$. If not noted otherwise, the used solvent was $\mathrm{C}_{6} \mathrm{D}_{6}$ and samples were measured at rt. In the case of reaction samples, a $\mathrm{D}_{2} \mathrm{O}$ capillary was used to provide an external lock frequency signal. To compensate for the low isotopic abundance of ${ }^{29} \mathrm{Si}$, the INEPT pulse sequence ${ }^{64,65}$ was used for the amplification of the signal for some of the spectra.

Elemental analyses were carried out using a Heraeus VARIO ELEMENTAR instrument. For a number of compounds, obtained elemental analysis showed too low carbon values, which is a typical problem for these compounds likely caused by silicon carbide formation during the combustion process. Multinuclear NMR spectra $\left({ }^{1} \mathrm{H},{ }^{13} \mathrm{C},{ }^{29} \mathrm{Si}\right)$ of these compounds are presented in the Supporting Information (SI) as proof of purity.

X-ray Structure Determination. For X-ray structure analyses, the crystals were mounted onto the tip of glass fibers, and data collection was performed with a BRUKER-AXS SMART APEX CCD diffractometer using graphite-monochromated Mo $\mathrm{K} \alpha$ radiation $(0.71073 \AA)$. The data were reduced to $F^{2}$ o and corrected for absorption effects with SAINT ${ }^{66}$ and SADABS, ${ }^{67,68}$ respectively. The structures were solved by direct methods and refined by full-matrix least-squares method (SHELXL97). ${ }^{69}$ If not noted otherwise, all nonhydrogen atoms were refined with anisotropic displacement parameters and all hydrogen atoms were located in calculated positions to correspond to standard bond lengths and angles. Crystallographic data (excluding structure factors) for the structures of compounds $4,6,14,17,18$, and 19 reported in this paper have been deposited with the Cambridge Crystallographic Data Center as supplementary publication nos. CCDC- 1818448 (4), 1853659 (6), 1853663 (14), 1853662 (17), 1853660 (18), and 1853661 (19). The data can be obtained free of charge at: http://www.ccdc.cam.ac.uk/ products/csd/request/. Figures of solid state molecular structures were generated using Ortep-3 as implemented in WINGX ${ }^{70}$ and rendered using POV-Ray 3.6 . $^{7}$

2,2,5,5-Tetramethyl-3,3,4,4-tetrakis(trimethylsilyl)-1-oxacyclopentasilane (4). From a solution of oligosilanylene diide 2 (1.59 $\mathrm{mmol})$ in THF $(5 \mathrm{~mL})$, the solvent was removed in vacuum and replaced by toluene $(5 \mathrm{~mL})$. To this solution, 1,2-dibromoethane $(1.65 \mathrm{mmol})$ in pentane $(10 \mathrm{~mL})$ was added dropwise, whereupon the decolorization and precipitation of a salt occurred. The solvent was removed in vacuum and the residue extracted with pentane three times. Crystallization from a concentrated solution at $-37{ }^{\circ} \mathrm{C}$ gave 4 $(0.703 \mathrm{~g}, 92 \%)$ as colorless crystals. Mp.: $144-146{ }^{\circ} \mathrm{C}$. NMR ( $\delta$ in ppm): ${ }^{1} \mathrm{H}: 0.46$ (s, $\left.12 \mathrm{H}, \mathrm{SiMe}_{2}\right), 0.35$ (s, 36H, $\left.\mathrm{SiMe}_{3}\right) .{ }^{13} \mathrm{C}: 6.3$
$\left(\mathrm{SiMe}_{2}\right), 3.9\left(\mathrm{SiMe}_{3}\right) .{ }^{29} \mathrm{Si}: 20.9\left(\mathrm{Me}_{2} \mathrm{SiO}\right),-9.6\left(\mathrm{SiMe}_{3}\right),-132.2$ $\left(\mathrm{Si}_{\mathrm{q}}\right)$. Anal. Calcd for $\mathrm{C}_{16} \mathrm{H}_{48} \mathrm{OSi}_{8}$ (481.24): C 39.93, $\mathrm{H}$ 10.05. Found C 37.09, H 10.20.

In the case of using a slight excess of 1,2-dibromoethane, the formation of 1,3-bis[bromobis(trimethylsilyl)silyl]tetramethyldisiloxane (5) is observed as a side product, which can be converted into 4 by addition of potassium graphite $\left(\mathrm{C}_{8} \mathrm{~K}\right)$. Selective formation of $\mathbf{5}$ can be achieved when adding 2 to a solution containing three-fold excess of 1,2-dibromoethane. 5: $\mathrm{NMR}\left(\delta\right.$ in ppm, toluene- $\left.\mathrm{D}_{2} \mathrm{O}\right):{ }^{29} \mathrm{Si}: 6.9$ $(\mathrm{SiO}),-13.0\left(\mathrm{SiMe}_{3}\right),-28.8(\mathrm{SiBr})$.

3,7-Dioxa-1,1,5,5-tetrakis(trimethysilyl)octamethylcyclooctasilane (6). A mixture of 1 (10.0 g, $15.9 \mathrm{mmol}$ ) and ${ }^{t} \mathrm{BuOK}$ (3.66 g, $32.5 \mathrm{mmol})$ in THF $(20 \mathrm{~mL})$ was stirred for $12 \mathrm{~h}$ at rt. After complete conversion to 2 (checked by ${ }^{1} \mathrm{H}$ and ${ }^{29} \mathrm{Si}$ spectroscopic analysis of a reaction sample), THF was removed in vacuum and replaced by toluene $(8 \mathrm{~mL})$. This solution was added dropwise to a solution of 1,3-dichlorotetramethyldisiloxane in toluene (10 mL). After $3 \mathrm{~h}$, the solvent was removed in vacuum from the orange solution. The residue was extracted with three portions of pentane and the extract filtered over Celite. After concentrating the volume of the solution, compound 6 was obtained as colorless crystals ( $4.59 \mathrm{~g}$, $47 \%$ ) by crystallization at $-37{ }^{\circ} \mathrm{C}$. Crystals suitable for crystallographic analysis were obtained by a further crystallization step from toluene. Mp.: $181-182{ }^{\circ} \mathrm{C}$. NMR ( $\delta$ in ppm): ${ }^{1} \mathrm{H}: 0.46(\mathrm{~s}, 24 \mathrm{H}$, $\left.\mathrm{SiMe}_{2}\right), 0.30$ (s, 36H, $\left.\mathrm{SiMe}_{3}\right) .{ }^{13} \mathrm{C}: 8.5\left(\mathrm{SiMe}_{2}\right), 3.2\left(\mathrm{SiMe}_{3}\right) .{ }^{29} \mathrm{Si}$ : $11.6(\mathrm{SiO}),-11.2\left(\mathrm{SiMe}_{3}\right),-135.2\left(\mathrm{Si}_{\mathrm{q}}\right)$. Anal. Calcd for $\mathrm{C}_{20} \mathrm{H}_{60^{-}}$ $\mathrm{O}_{2} \mathrm{Si}_{10}$ (613.55): C 39.15, H 9.86. Found C 37.59, H 9.82.

Dipotassium 3,7-Dioxa-1,5-bis(trimethylsilyl)octamethylcyclooctasilanyl-1,5-diide-(THF) $)_{x}$ (7). A mixture of dioxacyclooctasilane 6 (250 mg, $0.41 \mathrm{mmol})$ and ${ }^{t} \mathrm{BuOK}(94 \mathrm{mg}, 0.84 \mathrm{mmol})$ in THF $(2 \mathrm{~mL})$ was stirred at ambient temperature for $12 \mathrm{~h}$. Removal of solvent gives the product in quantitative yield as a brownish solid. NMR (THF/D 20 -capillary, $\delta$ in ppm): ${ }^{29} \mathrm{Si}: 23.3,-9.6,-190.7$. NMR $\left(\mathrm{C}_{6} \mathrm{D}_{6}\right.$-THF (a very small amount of THF was added as the product is nearly insoluble in $\left.\left.\mathrm{C}_{6} \mathrm{D}_{6}\right)\right):{ }^{1} \mathrm{H}: 3.53$ (THF), 1.55 (THF), 0.47 (s, 24H, $\mathrm{SiMe}_{2}$ ), 0.24 (s, 18H, $\mathrm{SiMe}_{3}$ ). ${ }^{13} \mathrm{C}: 67.9$ (THF), 25.9 (THF), $11.8\left(\mathrm{SiMe}_{2}\right), 6.8\left(\mathrm{SiMe}_{3}\right) .{ }^{29} \mathrm{Si}: 24.7(\mathrm{SiO}),-9.9\left(\mathrm{SiMe}_{3}\right)$, -188.0 (SiK).

3,7-Dioxa-1,5-bis(trimethylsilyl)octamethylbicyclo[3.3.0]octasilane (8). A mixture of dioxacyclooctasilane $6(360 \mathrm{mg}, 0.59$ $\mathrm{mmol})$ and ${ }^{t} \mathrm{BuOK}(135 \mathrm{mg}, 1.20 \mathrm{mmol})$ in THF $(5 \mathrm{~mL})$ was stirred at ambient temperature for $12 \mathrm{~h}$. After almost complete removal of THF, toluene $(5 \mathrm{~mL})$ was added and then a solution of 1,2dibromoethane $(119 \mathrm{mg}, 0.63 \mathrm{mmol})$ in pentane $(5 \mathrm{~mL})$ was added dropwise, whereupon a white precipitate was observed. After $15 \mathrm{~min}$, the solvents were removed in vacuum and the remaining residue was extracted with three portions of pentane (4-5 mL each). Evaporation of the solvent gave product 8 and some oligomeric byproducts $(0.257$ $\mathrm{g})$ as a colorless oil. $\mathrm{NMR}\left(\mathrm{C}_{6} \mathrm{D}_{6}, \delta\right.$ in ppm): ${ }^{1} \mathrm{H}: 0.46(\mathrm{~s}, 12 \mathrm{H}$, $\left.\mathrm{SiMe}_{2}\right), 0.42\left(\mathrm{~s}, 12 \mathrm{H}, \mathrm{SiMe}_{2}\right), 0.31\left(\mathrm{~s}, 18 \mathrm{H}, \mathrm{SiMe}_{3}\right) .{ }^{13} \mathrm{C}: 6.5\left(\mathrm{SiMe}_{2}\right)$, $5.6\left(\mathrm{SiMe}_{2}\right), 2.8\left(\mathrm{SiMe}_{3}\right) .{ }^{29} \mathrm{Si}: 22.2(\mathrm{SiO}),-10.0\left(\mathrm{SiMe}_{3}\right),-132.9$ $\left(\mathrm{Si}_{\mathrm{q}}\right)$. Anal. Calcd for $\mathrm{C}_{14} \mathrm{H}_{42} \mathrm{O}_{2} \mathrm{Si}_{8}$ (467.17): C 35.99, $\mathrm{H}$ 9.06. Found C $35.06, \mathrm{H} 8.99$.

3,7,10-Trioxa-1,5-bis(trimethylsilyl)octamethylbicyclo[3.3.3] undecasilane (9). A solution of dipotassium 3,7-dioxacyclooctasilanyl-1,5-diide 7 (obtained from 6 (470 $\mathrm{mg}, 0.77 \mathrm{mmol}$ ) and $\left.{ }^{t} \mathrm{BuOK}(176 \mathrm{mg}, 1.57 \mathrm{mmol})\right)$ in $\mathrm{THF}(3 \mathrm{~mL})$ and pentane $(3 \mathrm{~mL})$ was added dropwise to a solution of 1,3-dichlorotetramethyldisiloxane $(156 \mathrm{mg}, 0.77 \mathrm{mmol})$ in pentane $(8 \mathrm{~mL})$. Immediately, the formation of a white precipitate was observed. After complete conversion (detected by NMR spectroscopy), the solvent was removed in vacuum, followed by extraction of the residue with pentane, filtration over Celite, and evaporation the compound was obtained as a colorless oil. Dissolving the oil in acetone and slow evaporation eventually gave 9 (376 mg) as colorless crystalline blocks, still contaminated with a small amount of oligomeric byproduct. Mp.: 205-208 ${ }^{\circ} \mathrm{C}$. NMR ( $\delta$ in ppm): ${ }^{1} \mathrm{H}: 0.48$ (s, 36H, $\left.\mathrm{SiMe}_{2}\right), 0.17$ (s, $\left.18 \mathrm{H}, \mathrm{SiMe}_{3}\right) \cdot{ }^{13} \mathrm{C}: 7.6\left(\mathrm{SiMe}_{2}\right), 2.2\left(\mathrm{SiMe}_{3}\right) \cdot{ }^{29} \mathrm{Si}: 10.9(\mathrm{SiO}),-15.3$ $\left(\mathrm{SiMe}_{3}\right),-136.2\left(\mathrm{Si}_{\mathrm{q}}\right)$. 
3,7,10-Trioxaoctamethylbicyclo[3.3.3] undecasilyl-1,5-dipotassium $(\mathrm{DME})_{X}(10)$. A solution of bicyclosilane $9(227 \mathrm{mg}, 0.38$ $\mathrm{mmol}$ ) and ${ }^{t} \mathrm{BuOK}(87 \mathrm{mg}, 0.78 \mathrm{mmol})$ in DME $(3 \mathrm{~mL})$ was stirred for $12 \mathrm{~h}$. After removal of the solvent in vacuum, product 10 was isolated in quantitative yield as a yellowish semisolid. NMR (DME/ $\mathrm{D}_{2} \mathrm{O}$-capillary, $\delta$ in ppm): ${ }^{1} \mathrm{H}: 0.10\left(\mathrm{~s}, 36 \mathrm{H}, \mathrm{SiMe}_{2}{ }^{29} \mathrm{Si}: 15.5\left(\mathrm{SiMe}_{2}\right)\right.$, -186.7 (SiK).

1,3-Bis[bis(trimethylsilyl)silanyl]tetramethyldisiloxane (11). A solution of $2(3.19 \mathrm{mmol})$ in THF $(2 \mathrm{~mL})$ was added dropwise to a $\mathrm{H}_{2} \mathrm{SO}_{4}(0.5 \mathrm{M}) / \mathrm{ice} / \mathrm{Et}_{2} \mathrm{O}$ mixture. The aqueous layer was extracted with $\mathrm{Et}_{2} \mathrm{O}(3 \times 5 \mathrm{~mL})$ and the combined organic phases were dried with $\mathrm{Na}_{2} \mathrm{SO}_{4}$. After evaporation of the solvent, dihydrosilane 11 (1.36 g, $88 \%)$ was obtained as a colorless oil. NMR $\left(\mathrm{C}_{6} \mathrm{D}_{6}, \delta\right.$ in ppm): ${ }^{1} \mathrm{H}$ : $2.57\left(\mathrm{~s}, 2 \mathrm{H},{ }^{1} \mathrm{~J}_{\mathrm{H}-\mathrm{Si}}=154 \mathrm{~Hz}, \mathrm{SiH}\right), 0.45\left(\mathrm{~s}, 12 \mathrm{H}, \mathrm{SiMe}_{2}\right), 0.28(\mathrm{~s}, 36 \mathrm{H}$, $\left.\mathrm{SiMe}_{3}\right) \cdot{ }^{13} \mathrm{C}: 7.0\left(\mathrm{SiMe}_{2}\right), 2.1 \quad\left(\mathrm{SiMe}_{3}\right),{ }^{29} \mathrm{Si}: 11.9(\mathrm{SiO}),-12.6$ $\left(\mathrm{SiMe}_{3}\right),-116.5(\mathrm{SiH})$. Anal. Calcd for $\mathrm{C}_{16} \mathrm{H}_{50} \mathrm{OSi}_{8}$ (483.26): C 39.77, H 10.43. Found C 38.43, H 10.59 .

1,3-Bis[chlorbis(trimethylsilyl)silyl]tetramethyldisiloxane (12). A solution of disiloxane $11(1.36 \mathrm{~g}, 2.81 \mathrm{mmol})$ in $\mathrm{CCl}_{4}(12$ $\mathrm{mL}$ ) was stirred at $\mathrm{rt}$ for 1 week. All volatiles were removed in vacuum, and dichlorodisiloxane $12(1.53 \mathrm{~g}, 98 \%)$ was obtained as a colorless oily liquid. NMR $\left(\mathrm{C}_{6} \mathrm{D}_{6}, \delta\right.$ in ppm): ${ }^{1} \mathrm{H}: 0.45(\mathrm{~s}, 12 \mathrm{H}$, $\left.\mathrm{SiMe}_{2}\right), 0.25$ (s, 36H, $\left.\mathrm{SiMe}_{3}\right) \cdot{ }^{13} \mathrm{C}: 4.3\left(\mathrm{SiMe}_{2}\right), 0.6\left(\mathrm{SiMe}_{3}\right) \cdot{ }^{29} \mathrm{Si}: 5.9$ $\left(\mathrm{SiMe}_{2}\right),-14.9\left(\mathrm{SiMe}_{3}\right),-19.7(\mathrm{SiCl})$. Anal. Calcd for $\mathrm{C}_{16} \mathrm{H}_{48^{-}}$ $\mathrm{OSi}_{8} \mathrm{Cl}_{2}$ (552.14): C 34.81, H 8.76. Found C 33.75, H 8.73.

2,5-Dioxa-1,1,4,4-tetrakis(trimethylsilyl)tetramethylcyclohexasilane (14). After stirring a mixture of dichlorodisiloxane 12 $(1.33 \mathrm{~g}, 2.41 \mathrm{mmol})$ and diethylamine $(1.76 \mathrm{~g}, 24.1 \mathrm{mmol})$ in toluene $(25 \mathrm{~mL})$ for 1 week, complete conversion to the diaminodisiloxane was detected by NMR spectroscopy. All volatiles were removed in vacuum, the residue was extracted with pentane $(3 \times 6 \mathrm{~mL})$, and filtered over Celite. Evaporation of the solvent gave raw diaminodisiloxane $13(1.06 \mathrm{~g}, 70 \%)$ as a yellowish oil. ${ }^{29} \mathrm{Si}: 8.4$ $\left.\left(\mathrm{SiMe}_{2}\right),-12.3\left(\mathrm{SiMe}_{3}\right),-18.5(\mathrm{SiN})\right)$. Then over a solution of 13 $(86 \mathrm{mg}, 0.16 \mathrm{mmol})$ in $\mathrm{Et}_{2} \mathrm{O}(1 \mathrm{~mL})$ carefully a layer of $\mathrm{MeOH}(3$ $\mathrm{mL}$ ) was placed. By slow evaporation of the solvent mixture, dioxacyclohexasilane $14(39 \mathrm{mg}, 49 \%)$ was obtained as colorless crystals. Mp.: $158-160{ }^{\circ} \mathrm{C}$. NMR $\left(\mathrm{C}_{6} \mathrm{D}_{6}, \delta\right.$ in ppm): ${ }^{1} \mathrm{H}: 0.36$ (s, $\left.12 \mathrm{H}, \mathrm{SiMe}_{2}\right), 0.28$ (s, 36H, SiMe $\left.{ }_{3}\right) .{ }^{13} \mathrm{C}: 5.6\left(\mathrm{SiMe}_{2}\right),-0.4\left(\mathrm{SiMe}_{3}\right)$. ${ }^{29} \mathrm{Si}: 1.6\left(\mathrm{OSiMe}_{2}\right),-7.0\left(\mathrm{OSi}_{\mathrm{q}}\right),-16.9\left(\mathrm{SiMe}_{3}\right)$. Anal. Calcd for $\mathrm{C}_{16} \mathrm{H}_{48} \mathrm{O}_{2} \mathrm{Si}_{8}$ (497.24): C 38.65, H 9.73. Found C 37.99, H 9.69.

3,7-Dioxa-1,5-bis(trimethylsilyl)-9-ytterbaoctamethylbicyclo[3.3.1] nonasilane (15). To a suspension of $\mathrm{YbI}_{2} \cdot(\mathrm{THF})_{2}(140$ $\mathrm{mg}, 0.25 \mathrm{mmol})$ in DME $(1 \mathrm{~mL})$, a solution of dipotassium cyclooctasilandiide 7 (obtained from $6(150 \mathrm{mg}, 0.24 \mathrm{mmol}$ ) and ${ }^{t} \mathrm{BuOK}(56 \mathrm{mg}, 0.50 \mathrm{mmol})$ ) in DME $(1 \mathrm{~mL})$ was added dropwise, causing immediate orange-brown colorization and formation of a precipitate. After stirring for $15 \mathrm{~min}$, the solvent volume was reduced by $50 \%$ and the residue was extracted with pentane $(3 \times 5 \mathrm{~mL})$ and filtered over Celite. After $24 \mathrm{~h}$, complex 15 (55 mg, 32\%) was isolated as crystalline orange plates (55 mg). Mp.: $160-162{ }^{\circ} \mathrm{C}$. NMR (DME/ $\mathrm{D}_{2} \mathrm{O}, \delta$ in ppm): ${ }^{1} \mathrm{H}: 0.30$ (s, 12H, SiMe $), 0.16\left(\mathrm{~s}, 12 \mathrm{H}, \mathrm{SiMe}_{2}\right), 0.03$ $\left(\mathrm{s}, 18 \mathrm{H}, \mathrm{SiMe}_{3}\right) \cdot{ }^{13} \mathrm{C}: 10.8\left(\mathrm{SiMe}_{2}\right), 10.3\left(\mathrm{SiMe}_{2}\right), 5.6\left(\mathrm{SiMe}_{3}\right) .{ }^{29} \mathrm{Si}$ : $20.6(\mathrm{SiO}),-8.8\left(\mathrm{SiMe}_{3}\right),-155.7(\mathrm{SiYb})$.

4-Oxa-2, 2,6,6-tetrakis(trimethylsilyl)tetramethylmagnesacyclohexasilane.(DME) (16). A solution of 2 (freshly prepared from disiloxane $1(157 \mathrm{mg}, 0.250 \mathrm{mmol}), \mathrm{KO}^{\mathrm{t}} \mathrm{Bu}(57 \mathrm{mg}, 0.50 \mathrm{mmol})$ in DME $(4 \mathrm{~mL})$ ) was evaporated to dryness. The orange residue was dissolved in $\mathrm{Et}_{2} \mathrm{O}(4 \mathrm{~mL})$ and added dropwise to a stirred solution of $\mathrm{MgBr}_{2}\left(\mathrm{Et}_{2} \mathrm{O}\right)(65 \mathrm{mg}, 0.25 \mathrm{mmol})$ in $\mathrm{Et}_{2} \mathrm{O}(4 \mathrm{~mL})$. The white suspension was stirred for another $30 \mathrm{~min}$. Quantitative formation of 16 was detected after $90 \mathrm{~min}$ by NMR spectroscopy of an aliquot sample. NMR $\left(\mathrm{D}_{2} \mathrm{O}\right.$-cap $/ \mathrm{Et}_{2} \mathrm{O}, \delta$ in ppm): ${ }^{1} \mathrm{H}: 3.32$ (ether), 1.05 (ether), 0.22 (s, 12H, $\mathrm{SiMe}_{2}$ ), $0.13\left(\mathrm{~s}, 36 \mathrm{H}, \mathrm{SiMe}_{3}\right) .{ }^{13} \mathrm{C}: 65.2$ (ether), 14.6 (ether), $8.6\left(\mathrm{SiMe}_{2}\right), 4.7\left(\mathrm{SiMe}_{3}\right) .{ }^{29} \mathrm{Si}: 15.2\left(\mathrm{SiMe}_{2}\right),-7.3$ $\left(\mathrm{SiMe}_{3}\right),-166.9(\mathrm{SiMg})$. For the purpose of further reaction, the obtained solution of 16 can be used as such. For analytical characterization, all volatiles were evaporated under reduced pressure, the colorless residue was extracted with pentane $(2 \times 5 \mathrm{~mL})$, and the combined extracts evaporated under vacuum, yielding 16 as a colorless, microcrystalline solid (61 mg, 41\%). The title compound can be crystallized from concentrated solutions in pentane at $-35^{\circ} \mathrm{C}$ NMR $\left(\mathrm{C}_{6} \mathrm{D}_{6}, \delta\right.$ in ppm): ${ }^{1} \mathrm{H}: 2.97$ (s, 6H, DME), 2.58 (bs, $4 \mathrm{H}$, $\mathrm{DME}$ ), 0.66 (s, 6H, $\left.\mathrm{SiMe}_{2}\right), 0.66\left(\mathrm{~s}, 6 \mathrm{H}, \mathrm{SiMe}_{2}\right), 0.43(\mathrm{~s}, 18 \mathrm{H}$, $\left.\mathrm{SiMe}_{3}\right), 0.43$ (s, 18H, $\mathrm{SiMe}_{3}$ ). ${ }^{13} \mathrm{C}$ : 69.6 (DME), 59.4 (DME), 9.9 $\left(\mathrm{SiMe}_{2}\right), 5.8\left(\mathrm{SiMe}_{3}\right) .{ }^{29} \mathrm{Si}: 15.2\left(\mathrm{SiMe}_{2}\right),-7.8\left(\mathrm{SiMe}_{3}\right),-166.7$ (SiMg).

4,10-Dioxa-2,2,6,6,8,8,12,12-octakis(trimethylsilyl)octamethyl-1,7-dizincacyclododecasilane (17). To a solution of compound 2 (obtained from $1(200 \mathrm{mg}, 0.32 \mathrm{mmol})$ and ${ }^{t} \mathrm{BuOK}$ $(74 \mathrm{mg}, 0.66 \mathrm{mmol}))$ in THF $(3 \mathrm{~mL})$, a solution of $\mathrm{ZnCl}_{2}$ in THF (2 $\mathrm{mL}$ ) was added dropwise. The previously dark orange solution turned pale yellow, and after $12 \mathrm{~h}$, the solvent was removed in vacuum and the residue extracted with pentane $(3 \times 4 \mathrm{~mL})$. After filtration over Celite, the product was crystallized at $-37{ }^{\circ} \mathrm{C}$ to give $17(132 \mathrm{mg}$, $76 \%)$ as colorless needles. Mp.: $222-223{ }^{\circ} \mathrm{C}$. NMR $\left(\mathrm{C}_{6} \mathrm{D}_{6}, \delta\right.$ in ppm): ${ }^{1} \mathrm{H}: 0.62$ (s, 24H, $\left.\mathrm{SiMe}_{2}\right), 0.41\left(\mathrm{~s}, 72 \mathrm{H}, \mathrm{SiMe}_{3}\right) .{ }^{13} \mathrm{C}: 9.7$ $\left(\mathrm{SiMe}_{2}\right), 4.6\left(\mathrm{SiMe}_{3}\right) .{ }^{29} \mathrm{Si}: 14.0(\mathrm{SiO}),-8.7\left(\mathrm{SiMe}_{3}\right),-125.6(\mathrm{SiZn})$. NMR (THF, $\mathrm{D}_{2} \mathrm{O}$-capillary, $\delta$ in ppm): ${ }^{1} \mathrm{H}: 0.32\left(\mathrm{~s}, 12 \mathrm{H}, \mathrm{SiMe}_{2}\right)$, $0.21\left(\mathrm{~s}, 36 \mathrm{H}, \mathrm{SiMe}_{3}\right) .{ }^{29} \mathrm{Si}: 16.3(\mathrm{SiO}),-5.8\left(\mathrm{SiMe}_{3}\right),-142.0(\mathrm{SiZn})$. Anal. Calcd for $\mathrm{C}_{32} \mathrm{H}_{96} \mathrm{O}_{2} \mathrm{Si}_{16} \mathrm{Zn}_{2}$ (1093.24): C 35.16, H 8.85. Found C $34.88, \mathrm{H} 8.42$.

1,1-Dicyclopentadienyl-4-oxa-2,2,6,6-tetrakis(trimethylsilyl)tetramethylzirconacyclohexasilane (18). To a suspension of zirconocene dichloride $(47 \mathrm{mg}, 0.16 \mathrm{mmol})$ in toluene $(2 \mathrm{~mL})$, a solution of $2(0.16 \mathrm{mmol})$ in toluene $(1 \mathrm{~mL})$ was added dropwise, causing the solution to turn first orange and then deep red. Formation of a precipitate was observed, and after $1 \mathrm{~h}$, complete conversion was detected by NMR spectroscopy. Removal of solvent, extraction of the residue with pentane $(3 \times 2 \mathrm{~mL})$, filtration over Celite, and slow evaporation of pentane gave $\mathbf{1 8}(104 \mathrm{mg}, 93 \%)$ as deep red crystalline blocks. Mp.: $131-132{ }^{\circ} \mathrm{C}$. NMR ( $\delta$ in ppm): ${ }^{1} \mathrm{H}: 6.28$ (s, 10H, Cp), 0.45 (s, 12H, SiMe $), 0.39$ (s, 36H, $\left.\mathrm{SiMe}_{3}\right) .{ }^{13} \mathrm{C}: 107.9$ (Cp), 9.7 $\left(\mathrm{SiMe}_{2}\right), 6.1\left(\mathrm{SiMe}_{3}\right) \cdot{ }^{29} \mathrm{Si}: 18.2\left(\mathrm{SiMe}_{2}\right),-5.6\left(\mathrm{SiMe}_{3}\right),-71.5(\mathrm{SiZr})$.

1,1-Dicyclopentadienyl-4-oxa-2,2,6,6-tetrakis(trimethylsilyl)tetramethylhafnacyclohexasilane (19). In an analogous way as described above for the synthesis of 18 , the hafnium compound 19 was obtained using $2(0.16 \mathrm{mmol})$ and hafnocene dichloride $(60 \mathrm{mg}$, $0.16 \mathrm{mmol})$. Crystallization of $19(0.106 \mathrm{~g}, 84 \%)$ as deep red crystalline blocks was achieved from the pentane extract at $-37^{\circ} \mathrm{C}$. Mp.: $180-182{ }^{\circ} \mathrm{C}$. NMR ( $\delta$ in ppm): ${ }^{1} \mathrm{H}: 6.22$ (s, 10H, Cp), 0.49 (s, $\left.12 \mathrm{H}, \mathrm{SiMe}_{2}\right), 0.39$ (s, 36H, SiMe $) .{ }^{13} \mathrm{C}: 108.1$ (Cp), $10.0\left(\mathrm{SiMe}_{2}\right)$, $6.6\left(\mathrm{SiMe}_{3}\right) .{ }^{29} \mathrm{Si}: 13.3\left(\mathrm{SiMe}_{2}\right),-4.9\left(\mathrm{SiMe}_{3}\right),-45.7(\mathrm{SiHf})$.

\section{ASSOCIATED CONTENT}

\section{Supporting Information}

The Supporting Information is available free of charge on the ACS Publications website at DOI: 10.1021/acs.organomet.9b00013.

Tabulated crystallographic data for $4,6,14,17,18$, and 19. Mechanistic proposal for the formation of 14 by hydrolysis of $13 .{ }^{1} \mathrm{H},{ }^{13} \mathrm{C}\{1 \mathrm{H}\}$, and ${ }^{29} \mathrm{Si}\{1 \mathrm{H}\}$ INEPT spectra of compounds 4-19 (PDF)

\section{Accession Codes}

CCDC 1818448 and 1853659-1853663 contain the supplementary crystallographic data for this paper. These data can be obtained free of charge via www.ccdc.cam.ac.uk/data_request/ cif, or by emailing data_request@ccdc.cam.ac.uk, or by contacting The Cambridge Crystallographic Data Centre, 12 Union Road, Cambridge CB2 1EZ, UK; fax: +44 1223336033.

\section{AUTHOR INFORMATION}

\section{Corresponding Authors}

*E-mail: christoph.marschner@tugraz.at (C.M.).

*E-mail: baumgartner@tugraz.at (J.B.). 


\section{ORCID $\odot$}

Judith Baumgartner: 0000-0002-9938-1813

Christoph Marschner: 0000-0001-8586-2889

\section{Funding}

Support for this study was provided by the Austrian Fonds zur Förderung der wissenschaf tlichen Forschung (FWF) via projects P-25124 (J.B.) and P-26417 (C.M.)

\section{Notes}

The authors declare no competing financial interest.

\section{ACKNOWLEDGMENTS}

The authors would like to express their gratitude to Dr. Johann Hlina for repeating some experiments to obtain additional NMR spectra.

\section{REFERENCES}

(1) Kayser, C.; Kickelbick, G.; Marschner, C. Simple Synthesis of Oligosilyl- $\alpha, \omega$-dipotassium Compounds. Angew. Chem., Int. Ed. 2002, 41, 989-992.

(2) Fischer, R.; Konopa, T.; Baumgartner, J.; Marschner, C. Small Cyclosilanes: Syntheses and Reactions toward Mono- and Dianions. Organometallics 2004, 23, 1899-1907.

(3) Fischer, R.; Konopa, T.; Ully, S.; Baumgartner, J.; Marschner, C. Route $\mathrm{Si}_{6}$ revisited. J. Organomet. Chem. 2003, 685, 79-92.

(4) Gaderbauer, W.; Zirngast, M.; Baumgartner, J.; Marschner, C.; Tilley, T. D. Synthesis of Polysilanylmagnesium Compounds. Organometallics 2006, 25, 2599-2606.

(5) Marschner, C.; Baumgartner, J.; Wallner, A. Structurally and Conformationally Defined Small Methyl Polysilanes. Dalton Trans 2006, 5667-5674.

(6) Wallner, A.; Wagner, H.; Baumgartner, J.; Marschner, C.; Rohm, H. W.; Kockerling, M.; Krempner, C. Structure, Conformation, and UV Absorption Behavior of Partially Trimethylsilylated Oligosilane Chains. Organometallics 2008, 27, 5221-5229.

(7) Wallner, A.; Hölbling, M.; Baumgartner, J.; Marschner, C. Structural and spectroscopic studies of silylated cyclo- and bicyclosilanes. Silicon Chem. 2007, 3, 175-185.

(8) Wallner, A.; Hlina, J.; Konopa, T.; Wagner, H.; Baumgartner, J.; Marschner, C.; Flörke, U. Cyclic and Bicyclic Methylpolysilanes and Some Oligosilanylene-Bridged Derivatives. Organometallics 2010, 29, 2660-2675.

(9) Wallner, A.; Hlina, J.; Wagner, H.; Baumgartner, J.; Marschner, C. Conformational Control of Polysilanes: the Use of $\mathrm{CH}_{2}$-Spacers in the Silicon Backbone. Organometallics 2011, 30, 3930-3938.

(10) Wallner, A.; Emanuelsson, R.; Baumgartner, J.; Marschner, C.; Ottosson, $\mathrm{H}$. Coupling of Disilane and Trisilane Segments Through Zero, One, Two, and Three Disilanyl Bridges in Cyclic and Bicyclic Saturated Carbosilanes. Organometallics 2013, 32, 396-405.

(11) Fischer, R.; Frank, D.; Gaderbauer, W.; Kayser, C.; Mechtler, C.; Baumgartner, J.; Marschner, C. $\alpha . \omega$-Oligosilyl Dianions and Their Application in the Synthesis of Homo- and Heterocyclosilanes. Organometallics 2003, 22, 3723-3731.

(12) Fischer, J.; Gaderbauer, W.; Baumgartner, J.; Marschner, C. Group 14 Hetero- Mono- and Bicyclosilanes. Heterocycles 2006, 67, 507-510.

(13) Wagner, H.; Wallner, A.; Fischer, J.; Flock, M.; Baumgartner, J.; Marschner, C. Rearrangement of Cyclic Silanes with Aluminum Trichloride. Organometallics 2007, 26, 6704-6717.

(14) Zirngast, M.; Baumgartner, J.; Marschner, C. Synthesis of Cyclic and Bicyclic Polysilanes of Variable Ring Sizes. Organometallics 2008, 27, 6472-6478.

(15) Markov, J.; Fischer, R.; Wagner, H.; Noormofidi, N.; Baumgartner, J.; Marschner, C. Open, cyclic, and bicyclic compounds of double silylated phosphorus and boron. Dalton Trans 2004, 21662169.
(16) Uhl, W.; Jasper, B.; Lawerenz, A.; Marschner, C.; Fischer, J. Heterozyklische Verbindungen mit fünfgliedrigen $\mathrm{ESi}_{4}$-Ringen $(\mathrm{E}=$ Ga, In). Z. Anorg. Allg. Chem. 2007, 633, 2321-2325.

(17) Arp, H.; Zirngast, M.; Marschner, C.; Baumgartner, J.; Rasmussen, K.; Zark, P.; Müller, T. Synthesis of Oligosilanyl Compounds of Group 4 Metallocenes with the Oxidation State +3 . Organometallics 2012, 31, 4309-4319.

(18) Fischer, R.; Zirngast, M.; Flock, M.; Baumgartner, J.; Marschner, C. Synthesis of a Hafnocene Disilene Complex. J. Am. Chem. Soc. 2005, 127, 70-71.

(19) Gaderbauer, W.; Balatoni, I.; Wagner, H.; Baumgartner, J.; Marschner, C. Synthesis and structural diversity of oligosilanylzinc compounds. Dalton Trans 2010, 39, 1598-1603.

(20) Kayser, C.; Kickelbick, G.; Marschner, C. Einfache Synthese von Oligosilyl- $\alpha, \omega$-dikaliumverbindungen. Angew. Chem. 2002, 114, $1031-1034$.

(21) Zirngast, M.; Flock, M.; Baumgartner, J.; Marschner, C. Group 4 Metallocene Complexes of Disilenes, Digermenes, and a Silagermene. J. Am. Chem. Soc. 2009, 131, 15952-15962.

(22) Zirngast, M.; Flörke, U.; Baumgartner, J.; Marschner, C. Oligosilylated group 4 titanocenes in the oxidation state +3 . Chem. Commun. 2009, 5538-5540.

(23) Arp, H.; Baumgartner, J.; Marschner, C.; Müller, T. A Cyclic Disilylated Stannylene: Synthesis, Dimerization, and Adduct Formation. J. Am. Chem. Soc. 2011, 133, 5632-5635.

(24) Arp, H.; Baumgartner, J.; Marschner, C.; Zark, P.; Müller, T. Coordination Chemistry of Cyclic Disilylated Stannylenes and Plumbylenes to Group 4 Metallocenes. J. Am. Chem. Soc. 2012, 134, 10864-10875.

(25) Arp, H.; Baumgartner, J.; Marschner, C.; Zark, P.; Müller, T. Dispersion Energy Enforced Dimerization of a Cyclic Disilylated Plumbylene. J. Am. Chem. Soc. 2012, 134, 6409-6415.

(26) Arp, H.; Marschner, C.; Baumgartner, J.; Zark, P.; Müller, T. Coordination Chemistry of Disilylated Stannylenes with Group 10 d10 Transition Metals: Silastannene vs Stannylene Complexation. J. Am. Chem. Soc. 2013, 135, 7949-7959.

(27) Hlina, J.; Arp, H.; Walewska, M.; Flörke, U.; Zangger, K.; Marschner, C.; Baumgartner, J. Coordination Chemistry of Cyclic Disilylated Germylenes and Stannylenes with Group 11 Metals. Organometallics 2014, 33, 7069-7077.

(28) Hlina, J.; Baumgartner, J.; Marschner, C.; Zark, P.; Müller, T. Coordination Chemistry of Disilylated Germylenes with Group 4 Metallocenes. Organometallics 2013, 32, 3300-3308.

(29) Hlina, J.; Baumgartner, J.; Marschner, C.; Albers, L.; Müller, T. Cyclic Disilylated and Digermylated Germylenes. Organometallics 2013, 32, 3404-3410.

(30) Walewska, M.; Hlina, J.; Baumgartner, J.; Müller, T.; Marschner, C. Basic Reactivity Pattern of a Cyclic Disilylated Germylene. Organometallics 2016, 35, 2728-2737.

(31) Zitz, R.; Arp, H.; Hlina, J.; Walewska, M.; Marschner, C.; Szilvási, T.; Blom, B.; Baumgartner, J. Open-Shell Lanthanide(II+) or -(III+) Complexes Bearing $\sigma$-Silyl and Silylene Ligands: Synthesis, Structure, and Bonding Analysis. Inorg. Chem. 2015, 54, 3306-3315.

(32) Zitz, R.; Hlina, J.; Gatterer, K.; Marschner, C.; Szilvási, T.; Baumgartner, J. Neutral "Cp-Free" Silyl-Lanthanide(II) Complexes: Synthesis, Structure, and Bonding Analysis. Inorg. Chem. 2015, 54, $7065-7072$.

(33) Zitz, R.; Hlina, J.; Aghazadeh Meshgi, M.; Krenn, H.; Marschner, C.; Szilvási, T.; Baumgartner, J. Using Functionalized Silyl Ligands To Suppress Solvent Coordination to Silyl Lanthanide(II) Complexes. Inorg. Chem. 2017, 56, 5328-5341.

(34) Aghazadeh Meshgi, M.; Zitz, R.; Walewska, M.; Baumgartner, J.; Marschner, C. Tuning the Si-N Interaction in Metalated Oligosilanylsilatranes. Organometallics 2017, 36, 1365-1371.

(35) Weinhold, F.; West, R. Hyperconjugative Interactions in Permethylated Siloxanes and Ethers: The Nature of the $\mathrm{SiO}$ Bond. J. Am. Chem. Soc. 2013, 135, 5762-5767.

(36) Weinhold, F.; West, R. The Nature of the Silicon-Oxygen Bond. Organometallics 2011, 30, 5815-5824. 
(37) Yokouchi, Y.; Ishida, S.; Onodera, T.; Oikawa, H.; Iwamoto, T. Facile synthesis and bridgehead-functionalization of bicyclo[3.3.3]pentasiloxanes. Chem. Commun. 2018, 54, 268-270.

(38) Matsumoto, K.; Oba, Y.; Nakajima, Y.; Shimada, S.; Sato, K. One-Pot Iterative Synthesis of Sequence-Controlled Oligosiloxanes. Angew. Chem. 2018, 130, 4727-4731.

(39) Brook, M. A. New Control Over Silicone Synthesis Using SiH Chemistry: The Piers Rubinsztajn Reaction. Chem. - Eur. J. 2018, 24, $8458-8469$.

(40) Satoh, Y.; Igarashi, M.; Sato, K.; Shimada, S. Highly Selective Synthesis of Hydrosiloxanes by Au-Catalyzed Dehydrogenative CrossCoupling Reaction of Silanols with Hydrosilanes. ACS Catal. 2017, 7, $1836-1840$.

(41) Matsumoto, K.; Sajna, K. V.; Satoh, Y.; Sato, K.; Shimada, S. By-Product-Free Siloxane-Bond Formation and Programmed OnePot Oligosiloxane Synthesis. Angew. Chem., Int. Ed. 2017, 56, 31683171.

(42) Stüger, H.; Eibl, M.; Hengge, E.; Kovacs, I. Permethylheteroatomcyclopolysilane mit heteroatomen der VI. Hauptgruppe. Darstellung und spektroskopische eigenschaften. J. Organomet. Chem. 1992, 431, 1-15.

(43) Jäger-Fiedler, U.; Köckerling, M.; Reinke, H.; Krempner, C. Discrete oxygen containing oligosilane dendrimers-modelling oxygen defects in silicon nanomaterials. Chem. Commun. 2010, 46, 45354537.

(44) Reuter, K.; Thiele, G.; Hafner, T.; Uhlig, F.; von Hänisch, C. von Synthesis and coordination ability of a partially silicon based crown ether. Chem. Commun. 2016, 52, 13265-13268.

(45) Pahl, J.; Elsen, H.; Friedrich, A.; Harder, S. Unsupported metal silyl ether coordination. Chem. Commun. 2018, 54, 7846-7849.

(46) Marschner, C. A. New and Easy Route to Polysilanylpotassium Compounds. Eur. J. Inorg. Chem. 1998, 1998, 221-226.

(47) Zirngast, M.; Baumgartner, J.; Marschner, C. Preparation, Structure and Reactivity of $\mathrm{Et}_{2} \mathrm{~N}\left(\mathrm{Me}_{3} \mathrm{Si}\right)_{2} \mathrm{SiK}$. Eur. J. Inorg. Chem. 2008, 2008, 1078-1087.

(48) Marsmann, H.; Raml, W.; Hengge, E. ${ }^{29}$ Si-Kernresonanzmessungen an Polysilanen 2. Isotetrasilane. Z. Naturforsch., B: J. Chem. Sci. 1980, 35, 1541-1547.

(49) Schumann, H.; Nickel, S.; Loebel, J.; Pickardt, J. Organometallic compounds of the lanthanides. 42. Bis(dimethoxyethane) lithium bis(cyclopentadienyl)bis(trimethylsilyl)lanthanide complexes. Organometallics 1988, 7, 2004-2009.

(50) Schumann, H.; Meese-Marktscheffel, J. A.; Hahn, F. E. Metallorganische Verbindungen der Lanthanoide LVIII. Zur Struktur des Dicyclopentadienyl-bis(trimethylsilyl)lutetat-anions. J. Organomet. Chem. 1990, 390, 301-308.

(51) Corradi, M. M.; Frankland, A. D.; Hitchcock, P. B.; Lappert, M. F.; Lawless, G. A. Synthesis, structure and reactivity of $[\mathrm{Yb}(\eta$ $\left.\left.\mathrm{C}_{5} \mathrm{Me}_{5}\right)\left\{\mathrm{Si}\left(\mathrm{SiMe}_{3}\right)_{3}\right\}(\mathrm{thf})_{2}\right]$. Chem. Commun. 1996, 2323-2324.

(52) Niemeyer, M. Reactions of Hypersilyl Potassium with RareEarth Metal Bis(Trimethylsilylamides): Addition versus Peripheral Deprotonation. Inorg. Chem. 2006, 45, 9085-9095.

(53) Lampland, N. L.; Pindwal, A.; Yan, K.; Ellern, A.; Sadow, A. D. Rare Earth and Main Group Metal Poly(hydrosilyl) Compounds. Organometallics 2017, 36, 4546-4557.

(54) Thalangamaarachchige, V. D.; Unruh, D. K.; Cordes, D. B.; Krempner, C. Synthesis, Structure, and Reactivity of Zwitterionic Divalent Rare-Earth Metal Silanides. Inorg. Chem. 2015, 54, 41894191.

(55) Farwell, J. D.; Lappert, M. F.; Marschner, C.; Strissel, C.; Tilley, T. D. The first structurally characterised oligosilylmagnesium compound. J. Organomet. Chem. 2000, 603, 185-188.

(56) Arnold, J.; Tilley, T. D.; Rheingold, A. L.; Geib, S. J. Preparation and Characterization of Tris(trimethylsilyl)silyl Derivatives of Zinc, Cadmium, and Mercury. X-Ray Crystal Structure of $\mathrm{Zn}\left[\mathrm{Si}\left(\mathrm{SiMe}_{3}\right)_{3}\right]_{2}$. Inorg. Chem. 1987, 26, 2106-2109.

(57) Nanjo, M.; Oda, T.; Mochida, K. Preparation and structural characterization of trimethylsilyl-substituted germylzinc halides, $\left(\mathrm{Me}_{3} \mathrm{Si}\right)_{3} \mathrm{GeZnX}(\mathrm{X}=\mathrm{Cl}, \mathrm{Br}$, and $\mathrm{I})$ and silylzinc chloride, $\mathrm{R}$ -
$\left(\mathrm{Me}_{3} \mathrm{Si}\right)_{2} \mathrm{SiZnCl}\left(\mathrm{R}=\mathrm{SiMe}_{3}\right.$ and $\left.\mathrm{Ph}\right)$. J. Organomet. Chem. 2003, 672, $100-108$

(58) Nanjo, M.; Oda, T.; Mochida, K. Preparation and Characterization of Tris(trimethylsilyl)germylzinc Chloride and Bis[tris(trimethylsilyl)germyl]zinc. Chem. Lett. 2002, 31, 108-109.

(59) Lampland, N. L.; Ellern, A.; Sadow, A. D. $\beta$-SiH rich zinc silyl compounds: Reductive elimination and $\beta$-hydrogen abstraction. Inorg. Chim. Acta 2014, 422, 134-140.

(60) Li, H.; Hung-Low, F.; Krempner, C. Synthesis and Structure of Zwitterionic Silylborates and Silylzincates with Pendant Polydonor Arms. Organometallics 2012, 31, 7117-7124.

(61) Kumada, M.; Yamaguchi, M.; Yamamoto, Y.; Nakajima, J.; Shiina, K. Synthesis of Some Methyldisilanes Containing Functional Groups. J. Org. Chem. 1956, 21, 1264-1268.

(62) Korlyukov, A. A.; Chernyavskaya, N. A.; Antipin, M. Y.; Lysenko, K. A.; Chernyavskii, A. I. Molecular and Crystal Structure of Octamethyl-1,4-dioxacyclohexasilane. Chem. Heterocycl. Compd. 2005, 41, 536-541.

(63) Pangborn, A. B.; Giardello, M. A.; Grubbs, R. H.; Rosen, R. K.; Timmers, F. J. Safe and Convenient Procedure for Solvent Purification. Organometallics 1996, 15, 1518-1520.

(64) Morris, G. A.; Freeman, R. Enhancement of Nuclear Magnetic Resonance Signals by Polarization Transfer. J. Am. Chem. Soc. 1979, $101,760-762$.

(65) Helmer, B. J.; West, R. Enhancement of ${ }^{29} \mathrm{Si}$ NMR Signals by Proton Polarization Transfer. Organometallics 1982, 1, 877-879.

(66) SAINTPLUS: Software Reference Manual, Version 6.45; BrukerAXS: Madison, WI, 1997-2003.

(67) Blessing, R. H. An empirical correction for absorption anisotropy. Acta Crystallogr., Sect. A: Found. Crystallogr. 1995, 51, $33-38$.

(68) Sheldrick, G. M. SADABS, Version 2.10; Bruker AXS Inc.: Madison, WI, 2003.

(69) Sheldrick, G. M. A short history of SHELX. Acta Crystallogr., Sect. A: Found. Crystallogr. 2008, 64, 112-122.

(70) Farrugia, L. J. WinGX and ORTEP for Windows: An Update. J. Appl. Crystallogr. 2012, 45, 849-854.

(71) POV-RAY 3.6; Persistence of Vision Raytracer Pty. Ltd.: Williamstown, Victoria, Australia, 2004. http://www.povray.org/ download/ (accessed on Sept 07, 2008). 